\title{
Economic regulators of nature management of countries and regions of the Economic corridor
}

\author{
Svetlana Ayusheeva ${ }^{1 *}$, and Anna Mikheeva ${ }^{1}$ \\ ${ }^{1}$ Baikal Institute of Nature Management of Siberian Branch of Russian Academy of Sciences, \\ Sakhyanovoy str. 6, Ulan-Ude, 670047, Russia
}

\begin{abstract}
The article actualizes scientific and practical approaches to the use of economic tools of nature management of countries and regions of the Economic Corridor. The features of economic regulation of environmental protection in Mongolia, the effect of some nature management tools in Russia and China are shown. An environmental and economic assessment of damage from anthropogenic activities, compensation payments and environmental protection investments of countries and regions is given. Positive dynamics are revealed, allowing to compensate for the amount of economic damage due to environmental pollution. Negative tendencies are identified that show a significant excess of economic damage from air pollution over pollution charges.
\end{abstract}

\section{Introduction}

The relevance of research on the economic regulators of nature management in countries and regions of the China-Mongolia-Russia Economic Corridor is determined by the need for long-term management decisions to conduct effective ecologically-oriented policies that allow a comprehensive analysis of the existing and possible environmental impacts, quickly determine decision-making risks, and evaluate cumulative impacts to develop mechanisms for the implementation of state, corporate, international native programs and projects.

The studies showed, that the economic mechanism of nature management in the countries of the Economic Corridor is carried out through the development, identification and determination of the following main components:

- financial security of environmental measures;

- formation of the structure of fixed assets for environmental purposes;

- assessment of capitalization of environmental protection investments;

- setting standards for fees and amounts of payments for the use of natural resources, emissions and discharges of pollutants into the environment, waste disposal and other types of harmful effects;

- $\quad$ setting limits on the use of natural resources, emissions and discharges of pollutants into the environment and waste disposal;

* Corresponding author: ayuscheeva2010@yandex.ru 
- provision of tax, credit and other benefits to nature users when they introduce lowwaste and resource-saving technologies and non-traditional types of energy, and other effective measures to protect the environment;

- assessment of natural resources, ecosystem services and functions;

- compensation payments for misallocation of resources; compensation in the prescribed manner for harm caused to the environment and human health and others.

The financing of environmental measures in the Russian regions of the Economic Corridor comes from the federal budget, the regional budget, and enterprises own funds. Financing environmental protection measures in Russia includes current expenses, capital repairs of fixed assets, environmental investments, expenses of executive authorities on the maintenance of the apparatus dealing with environmental protection, expenses on research and development, as well as expenses on education in the field of environmental protection. The financing of environmental measures in Mongolia comes from the state budget, various environmental funds, as well as from loans and grants from international organizations. In China, environmental measures are carried out at the expense of state funds, environmental funds and bank loans.

Many scientists currently confirm that environmental investment in Russia and Mongolia follows the residual principle [1-4], while the contribution of nature-exploiting activities to gross domestic product is $25 \%$ and higher. According to scientists, the sufficiency of environmental investment is $8-10 \%$ of GDP $[1,2]$.

Kotko A., Price C., Farley J., Christy M. [5-8] consider the effectiveness of investments in environmental protection as an assessment of the increase in the cost of ecosystem products and services as a result of environmental investments, as well as taking into account the growth of their relative value over time. E. Kucharska-Stasiak, K. Olbińska [9] believe that environmental investment effectiveness should be evaluated in terms of assessing their impact on the value of property acquired by the company as a result of environmental protection investments because the environmental costs and results of the investment project reflect the interests of the whole society. The capitalization of investments in nature conservation is presented as the preservation of the irreproducible and the restoration of a reproducible natural resource $[1,9]$. It may turn out to be more effective than its cost-effective spending if the growth rate of its capital value exceeds the possible profitability of its current productive investment.

In Russia pollution charges (within the limits of standards) are included in the cost of production. Pollution charges are paid from the profits of enterprises. Russian practice shows, enterprises do not seek to reduce excess pollution. By paying pollution charges from profit, they reduce the profitability of production. Enterprises could finance their own environmental measures and reduce the level of excess pollution. However, business entities prefer to pollute and pay for pollution today than to invest today and reduce pollution tomorrow, which proves the absence of their environmental strategy [10].Therefore, at present, the development of a scientific basis is needed to optimize the structure and nature management regimes, and to assess the assimilation properties of environmental components. At the same time, possible changes should not upset the balance between natural and man-made systems, increase man-made loads and economic losses.

\section{Materials and methods}

The main methods for assessment the effectiveness of economic nature management tools are a comparative analysis of the effectiveness of environmental investments, comparing the economic damage from air pollution with compensation payments for pollution, 
comparing the amount of economic damage caused by pollution with gross domestic product, assessing the quality of the air in different regions and countries.

In the countries and regions of the China-Mongolia-Russia Economic Corridor, the economy is developing on an extensive basis. All countries are characterized by high environmental intensity of economies and increased environmental degradation [11-13].

Currently, the main features and problems in the economy of Mongolia are: a high level of nature-exploiting activities in the GDP structure, a high concentration of exports on a narrow group of mineral products (more than 90.0\%) (coal, copper, molybdenum), a high concentration of exports on one foreign market (PRC), a high level of dependence on one importer of oil products (Russia), a high level of dependence on foreign direct investment in the mining sector, a high level of external debt (in 2018, 220.8\% to GDP), the imperfection and instability of the legislation of Mongolia on foreign investment [14].

The high resource intensity of the Mongolian economy, as well as environmental problems (high levels of urban air pollution, increased desertification processes and others) require an increased level of environmental costs. The Republic of Buryatia, the Irkutsky Region and the Zabaikalsky Region are characterized by a high proportion of the mining industry in GRP (coal, gold, oil, gas), and a high nature intensity of the economy (table 1). The level of subsidization of the consolidated budget remained high (in 2016, 54.6\% - the Republic of Buryatia, 43.6\% - Zabaikalsky Region, 28.1\% - Irkutsky Region) [15].

Table 1. Comparative assessment of the anthropogenic load of countries and regions of the ChinaMongolia-Russia Economic Corridor (2015)

\begin{tabular}{|c|c|c|c|c|c|}
\hline Indicators & $\begin{array}{c}\text { Republic of } \\
\text { Buryatia } \\
\text { (Russia) }\end{array}$ & $\begin{array}{c}\text { Zabaikalsky } \\
\text { Region } \\
\text { (Russia) }\end{array}$ & $\begin{array}{c}\text { Irkutsky } \\
\text { Region } \\
\text { (Russia) }\end{array}$ & Mongolia & $\begin{array}{c}\text { Inner } \\
\text { Mongolia } \\
\text { (PRC) }\end{array}$ \\
\hline $\begin{array}{c}\text { Gross domestic product } \\
\text { per capita, thousand } \\
\text { dollars / person }\end{array}$ & 3.4 & 3.8 & 6.9 & 3.8 & 11.1 \\
\hline $\begin{array}{c}\text { Share of nature-exploiting } \\
\text { industries in the structure } \\
\text { of gross product,\% }\end{array}$ & 15.4 & 21.3 & 35.9 & 32.1 & 26 \\
\hline agriculture & 6.1 & 5.8 & 6 & 13.4 & 6.5 \\
\hline mining industry & 4.1 & 11.2 & 24.6 & 17.1 & 6.9 \\
\hline electric power industry & 5.2 & 4.3 & 5.3 & 1.6 & 12.6 \\
\hline $\begin{array}{c}\text { Sown area of agricultural } \\
\text { crops, ha / person }\end{array}$ & 0.2 & 0.3 & 0.2 & 0.2 & 0.3 \\
\hline $\begin{array}{c}\text { Livestock number, conv. } \\
\text { heads / person }\end{array}$ & 0.4 & 0.1 & 0.5 & 3.0 & 0.5 \\
\hline $\begin{array}{c}\text { Pollutant emissions from } \\
\text { stationary sources, conv. } \mathrm{t}\end{array}$ & 3.4 & 2.4 & 8.4 & 4.2 & 38.7 \\
\hline / person & & & & \\
\hline
\end{tabular}

Sources: [16-19]

The highest level of pollutant emissions was detected in Inner Mongolia (PRC) - 38.7 conv. $\mathrm{t}$ / person. Identified in Mongolia indicator 4.2 conv. $\mathrm{t} /$ person is a rough estimate of the World Bank, because monitoring emissions from stationary sources of pollution in Mongolia is imperfect. Air pollution is the main environmental problem in the regions of the China-Mongolia-Russia Economic Corridor due to anthropogenic activities, natural processes, forest fires, as well as transboundary transport of polluted air masses. Anthropogenic changes in the air environment occur due to emissions of pollutants as a result of production and other activities of enterprises, organizations and institutions (stationary and area sources), mobile vehicles (cars, rail and air transport), heating boilers and stoves in the private residential sector.

According to the research of Mikheeva A. [20], the territory of Buryatia refers to 
territories with low self-cleaning capabilities. The quantitative assessment of factors favouring dispersion is much lower than the assessment of factors that impede the purification of the atmosphere. The climatic potential of self-purification of the atmosphere of the considered regions of China, Mongolia and Russia is characterized as low, due to the action of the Asian anticyclone. The powerful temperature inversions form a delay layer and impede the transport of impurities.

The high reproductive ability to atmospheric oxygen of Buryatia, Zabaikalsky region and Irkutsky Region is determined by forest cover (60\% on average), eliminates low opportunities for self-purification of atmospheric air. The low level of atmospheric oxygen reproduction is typical for residential territories [20]. The forest cover of Mongolia and Inner Mongolia is low, compared to the Russian regions. According to statistics, the share of the forest area of Mongolia in 2015 was 7.3\%, in Inner Mongolia (China) - 21\% [17,18].

\section{Results}

The main activity polluting the atmospheric air is the production, transmission and distribution of electricity, gas, steam and hot water in all the studied Russian cities of the China-Mongolia-Russia Economic Corridor. In the Irkutsky region, 31\% of the generated electricity comes from coal-fired power plants, and 69\% from hydroelectric power stations [21]. In Zabaikalsky Region, Republic of Buryatia, Inner Mongolia (PRC) and Mongolia, electricity is generated mainly from coal-fired power plants. According to the statistics of Mongolia, in 2015 the volume of electricity production was 5.2 billion $\mathrm{kWh}$, of which 1.4 billion kWh (26.9\%) was import [18].

The development and implementation of an economic mechanism of nature management in Mongolia has been developed relatively recently due to the emergence and aggravation of environmental problems, an increase in the anthropogenic load in residential areas. Currently the basis of economic regulation is a system of payments for the use of natural resources, environmental pollution, fines and lawsuits for violation of environmental laws [22].

The first law regulating economic relations in nature management was the law of Mongolia "On payment for the use of water bodies", adopted in 1995 and establishing the basic rules for the formation of fees for water use (payers, types of use of water bodies, ranges of payment rates, benefits for payment, procedure for its accrual, collection and nature of distribution). In accordance with Art. 11 of the Law "On Subsoil" a fee is established for the right to use subsoil, according to which "business units and organizations engaged in the extraction of mineral resources are required to eliminate losses arising from environmental pollution and wasteful use, destruction and damage to its wealth." In addition, the law provides for payments to the somon (district) local administrative bodies of a cash deposit as a financial guarantee for the implementation of these measures. This law (Article 58) defines liability for violation of subsoil legislation. So, in case of violation of the law, the perpetrators are brought to economic responsibility, and its size is clearly insufficient to compensate for even the smallest environmental damage.

In addition, nature management in Mongolia is regulated by mechanisms including, payments for the reproduction of the mineral resource base, forest income, deductions for reproduction, conservation and protection of forests, payment for water withdrawal by industrial enterprises, land tax from land users, fee for permission to shoot commercial animals. Payments for the negative impact on the environment were introduced from January 1, 2012 for organizations with sources of air pollution [22]. It should be noted that the normatively established fees for the use of natural resources and their pollution do not 
reflect the real economic value of natural resources, nor do they stimulate the use of lowwaste and environmentally friendly technologies by nature users.

\section{Discussion}

The results of the authors' calculations for the considered regions revealed the highest indicator of environmental protection costs in GRP in the Republic of Buryatia (table 2). The lack of statistical information on the current costs of environmental protection and the cost of major repairs of fixed assets underestimate the value of this indicator for Mongolia and Inner Mongolia (China). Among Russian regions, the highest value of the share of environmental investments in the total volume of investments $(1.3 \%)$ was also observed in the Republic of Buryatia. The low indicator for Inner Mongolia (China) $(0.5 \%)$ is associated with a significant amount of total investment in fixed assets in the region. A comparison of environmental investments per $1 \mathrm{~km}^{2}$ of territory revealed the largest value in Inner Mongolia (325.5 dollars per $\mathrm{km}^{2}$ ).

Table 2. Economic tools of nature management of countries and regions of the Economic corridor (2016)

\begin{tabular}{|c|c|c|c|c|c|}
\hline Indicators & $\begin{array}{c}\text { Republic of } \\
\text { Buryatia } \\
\text { (Russia) }\end{array}$ & $\begin{array}{c}\text { Zabaikalsky } \\
\text { Region } \\
\text { (Russia) }\end{array}$ & $\begin{array}{c}\text { Irkutsky } \\
\text { Region } \\
\text { (Russia) }\end{array}$ & Mongolia & $\begin{array}{c}\text { Inner } \\
\text { Mongolia } \\
\text { (PRC) }\end{array}$ \\
\hline $\begin{array}{c}\text { Environmental protection } \\
\text { costs in GDP (GRP), }\end{array}$ & 1.6 & 1.4 & 1.0 & 0.1 & 0.4 \\
\hline $\begin{array}{c}\text { Share of environmental } \\
\text { investments in total } \\
\text { investment in fixed } \\
\text { assets, } \%\end{array}$ & 1.3 & 0.9 & 0.9 & 0.6 & 0.5 \\
\hline $\begin{array}{c}\text { Volume of investments } \\
\text { aimed at protecting the } \\
\text { environment, USD / km }\end{array}$ & 10.9 & 5.4 & 14.8 & 31.3 & 325.5 \\
\hline $\begin{array}{c}\text { Pollution payments in the } \\
\text { total amount of tax and } \\
\text { non-tax revenues,\% }\end{array}$ & 0.2 & 0.3 & 0.6 & 0.04 & - \\
\hline $\begin{array}{c}\text { Natural resource taxes in } \\
\text { the total amount of tax and } \\
\text { non-tax revenues, \% }\end{array}$ & 2.6 & 4.2 & 1.9 & 0.3 & 5.9 \\
\hline
\end{tabular}

\section{Sources: [16-19]}

In the considered Russian regions, pollution charges accounted for only $0.2-0.6 \%$ of the total tax and non-tax revenues of the consolidated budget. The main environmental pollutants are private enterprises in the region (Public Joint-Stock Company TGK-14, Open Joint-Stock Company Vodokanal, Public Joint-Stock Company Irkutskenergo and others), however, in the structure of environmental investments, the enterprises' own funds accounted for the Republic of Buryatia in 2008 - 3.6\%, in $2010-0 \%$, in $2015-12.2 \%$. In Buryatia the main investor of environmental protection measures was the federal budget: $2008-81.6 \%, 2010-81.5 \%, 2015-87.8 \%$ [10].

In Mongolia, in 2016 pollution charges in the total amount of tax and non-tax revenues of the state budget of Mongolia amounted to only $0.04 \%$, natural resource taxes - $3 \%$. The main payers of natural resource taxes in Mongolia are processing enterprises $(7.2 \%)$, households $(2.7 \%)$, agricultural enterprises $(2.4 \%)$, enterprises for the production of electricity, steam and hot water $(2.1 \%)$. Mongolian coal mining enterprises account for $92.6 \%$ of all pollution charges [18]. 
In Russia, the rates of fees for negative effects on atmospheric air are applied for 159 substances. In Mongolia, the charge for air pollution is determined by 4 components (sulphur dioxide, nitrogen dioxide, carbon monoxide, solids), the rates for which are very low. It is expected that in the future the principle of payment for pollution of water resources will be implemented $[11,22]$.

In China from 1978 to 2017 enterprises paid sewage treatment fee. Pollution charge rates varied geographically. In 2014 in Inner Mongolia (PRC), they amounted to 1.2 yuan for sulphate discharge in the pollution equivalent, 1.4 yuan for chemical oxygen demand (COD) in the pollution equivalent; in Beijing, sulphate discharge rates are 9.5 yuan and COD 10 yuan [23]. In connection with the growing problems of ecosystem degradation, from January 1, 2018, the Law on Environmental Protection was adopted in China, according to which enterprises pay for pollution of atmospheric air, water, soil and noise pollution [24]. Table 3 shows the pollution charge rates in Russia and China.

Table 3. Pollution charge rates in the countries of the China-Mongolia-Russia Economic Corridor (2018)

\begin{tabular}{|c|c|c|c|c|}
\hline & \multirow{2}{*}{ Pollutants } & \multicolumn{2}{|c|}{ Russian Federation } & $\begin{array}{c}\text { China } \\
\text { (mining enterprises) }\end{array}$ \\
\hline & & rouble / t & yuan / t & $\begin{array}{l}\text { yuan / pollution } \\
\text { equivalent }\end{array}$ \\
\hline \multirow{4}{*}{ 光 } & Solids & $\begin{array}{l}36.6- \\
182.4\end{array}$ & $3.6-18.2$ & \multirow{4}{*}{$1.2-12$} \\
\hline & Sulfur dioxide & 45.4 & 4.5 & \\
\hline & Nitrogen oxide & 93.5 & 9.4 & \\
\hline & Carbon monoxide & 1.6 & 0.2 & \\
\hline \multirow{4}{*}{ 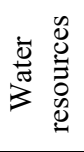 } & Sulfates & 6 & 0.6 & \multirow{4}{*}{$1.4-14$} \\
\hline & Chlorides & 2.4 & 0.2 & \\
\hline & Nitrate anions & 14.9 & 1.5 & \\
\hline & Phenols & 735534.3 & 73553.4 & \\
\hline \multirow{5}{*}{ 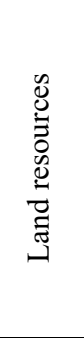 } & $\begin{array}{c}\text { Coal gangue (V Hazard } \\
\text { Class) }\end{array}$ & $1.1-17.3$ & $0.1-1.7$ & 5 \\
\hline & Tailings (IV Hazard Class) & 663.2 & 66.3 & \multirow{2}{*}{15} \\
\hline & (V Hazard Class) & $1.1-17.3$ & $0.1-1.7$ & \\
\hline & $\begin{array}{c}\text { Hazardous wastes (I Hazard } \\
\text { Class) }\end{array}$ & 4643.7 & 464.4 & 1000 \\
\hline & $\begin{array}{l}\text { Smelting slag, fly ash, } \\
\text { slag and other solid } \\
\text { wastes (V Hazard Class) }\end{array}$ & $1.1-17.3$ & $0.1-1.7$ & 25 \\
\hline
\end{tabular}

In China, the rates for the disposal of 1 ton of hazardous waste are significantly higher (1000 yuan / ton) than in Russia (464.4 yuan / ton), as well as for the placement of 1 ton of overburden produced by coal gangue ( 5 yuan / ton) and 1 ton of smelting slag, fly ash, slag and other solid wastes (25 yuan / ton). In general, the rates for air pollution and water resources in the two countries are comparable. The introduction of charges for air pollution is very important for Inner Mongolia (PRC), because the region is the largest producer of electricity in China, based on the burning of coal.

There are not noise pollution charges in Russia and Mongolia, while progressive noise pollution charges are applied in China (350 yuan / month (for exceeding the standard by 1-3 decibels), 700 yuan / month (for exceeding the standard for 4-6 decibels), etc.). 


\section{Conclusion}

According to the studies of many scientists, air pollution significantly affects the country's economy: labour productivity decreases, health care costs rise, crop yields decrease, and the useful life of material assets decreases [25]. According to OECD estimates, in 2015, the economic damage from air pollution amounted to $0.3 \%$ of world GDP, in addition, it entailed social support costs, which amounted to $6 \%$ of world GDP [26]. Our studies have shown significant economic damage to the economy of the regions from air pollution (table 4).

Table 4. Compensation of economic damage from air pollution in the regions of the China-MongoliaRussia Economic Corridor (2016)

\begin{tabular}{|c|c|c|c|c|c|}
\hline Indicators & $\begin{array}{c}\text { Republic of } \\
\text { Buryatia } \\
\text { (Russia) }\end{array}$ & $\begin{array}{c}\text { Zabaikalsky } \\
\text { Region } \\
\text { (Russia) }\end{array}$ & $\begin{array}{c}\text { Irkutsky } \\
\text { Region } \\
\text { (Russia) }\end{array}$ & Mongolia & $\begin{array}{c}\text { Inner } \\
\text { Mongolia } \\
\text { (PRC) }\end{array}$ \\
\hline $\begin{array}{c}\text { Economic damage } \\
\text { from air pollution, } \\
\text { thousand rouble }\end{array}$ & 290007.7 & 949899.2 & 5926256.2 & 3404647 & $\begin{array}{c}8048091 . \\
6\end{array}$ \\
\hline $\begin{array}{c}\text { Economic damage } \\
\text { from air pollution in } \\
\text { GDP,\% }\end{array}$ & 0.1 & 0.4 & 0.6 & 0.0004 & 0.04 \\
\hline $\begin{array}{c}\text { Payments for air } \\
\text { pollution, thousand } \\
\text { rouble }\end{array}$ & 32935.1 & 26458.3 & 302435.5 & 596968.0 & - \\
\hline $\begin{array}{c}\text { The ratio of economic } \\
\text { damage and pollution } \\
\text { payments, times }\end{array}$ & 8.8 & 35.9 & 19.6 & 5.7 & - \\
\hline
\end{tabular}

Sources: [15-18]

The highest level of economic damage in the GRP was detected in Irkutsky Region $(0.6 \%)$ and Zabaikalsky Region $(0.4 \%)$. The lack of pollution charges is characteristic of all the studied regions. In China, the ratio of economic damage to pollution charges can be calculated starting in 2018 after the introduction of pollution charges.

Inadequate environmental investment in enterprises' own funds in Russia, pollution charges in Russia and Mongolia, obsolescence (Russia) or insufficient environmental protection funds (China, Mongolia), low ability of the environment to self-clean (all regions) are the reasons for very high concentrations of pollutants in atmosphere of large cities of the Economic Corridor (table 5).

Table 5. Average annual concentrations of major pollutants in the cities of the China-MongoliaRussia Economic Corridor, $\mu \mathrm{g} / \mathrm{m} 3$ (2015)

\begin{tabular}{|c|c|c|c|c|}
\hline Cities & $\mathrm{SO}_{2}$ & $\mathrm{NO}_{2}$ & $\mathrm{PM}_{2.5}$ & $\mathrm{PM}_{10}$ \\
\hline Ulan-Ude (Republic of Buryatia, Russia) & 10 & 44 & \multicolumn{2}{|c|}{63 (solids) } \\
\hline Irkutsk (Irkutsky Region, Russia) & 55 & 48 & \multicolumn{2}{|c|}{59.5} \\
\hline Hohhot (Inner Mongolia, PRC) & 34 & 41 & 43 & 104 \\
\hline Ulaanbaatar (Mongolia) & 37 & 33 & 100 & 140 \\
\hline
\end{tabular}

Sources: [11, 12, 28-30]

The research results prove the insufficiency of modern economic tools of nature management in Russia and Mongolia, the need to develop new mechanisms to stimulate rational environmental management for polluting enterprises. The situation in Mongolia of "free" nature of natural goods used in the economy or their minimum prices become one of the reasons for the irrational use of natural resources. In such conditions, a mechanism for optimizing nature management is needed, which should include a set of tools of financial impact on nature users that stimulate environmental protection measures. The green 
financial system in China that is being actively formed at present (green shares, green bonds, green loans, green insurance) is supported at all levels by the Chinese Government [30-32]. Chinese banks offer an increased interest rate for enterprises expanding dirty production. In 2017, in order to reduce emissions from enterprises, the carbon emissions trading market began to operate, which will entail the development of carbon financial products (futures, swaps, options and others). The development of green finance in China represents a new direction in the development of the international financial system.

This work was carried out according to the State Order of the Baikal Institute of Nature Management of Siberian Branch of Russian Academy of Sciences.

\section{References}

1. S. Bobylev, A. Goryacheva. Int. Organisations Research Journal. 14(1) 225-236 (2019) DOI: 10.17323/1996-7845-2019-01-13

2. I. Potravny, N. Yashalova, V. Gassiy, Ch. Ferreyra. Economy of Region. 15(3), 806821 (2019) DOI: 10.17059/2019-3-14

3. N. Pakhomova, K. Richter, V. Zhigalov, A. Malova. Economy of Region. 13(1), 183 195 (2017) DOI: 10.17059/2017-1-17

4. I. Glazyrina, L.Faleychik, I. Zabelina IOP Conference Series: Earth and Environmental Science 190, 1 (2018) DOI: 10.1088/1755-1315/190/1/012008

5. A. Kotko. Bulletin of the Russian Academy of Sciences. Geographical series (2005)

6. C. Price. International society for ecological economics, 69(10), 1895-1903 (2010) DOI: $10.1016 /$ j.ecolecon.2010.04.024

7. J. Farley, R. Costanza. Ecological Economics, 69(11), 2060-2068 (2010) DOI: 10.1016/j.ecolecon.2010.06.010

8. M. Christy, I. Fazey, R. Cooper, T. Hyde, J. Kenter. Ecological Economics 83, 67-78 (2012) DOI: 10.1016/j.ecolecon.2012.08.012

9. E. Kucharska-Stasiak, K. Olbińska. Real Estate Management and Valuation 26 (2) (2018) DOI: 10.2478/remav-2018-0016

10. I. Karnaukh, A. Mikheeva, S. Ayusheeva, T. Bardakhanova MATEC Web of Conferences, 193, 20 (2018) DOI: 10.1051/matecconf/201819305019

11. Air pollution in Mongolia: Opportunities for further actions / Public expenditure review. AARC Consultancy Dublin, Ireland. https://www.mn.undp.org/content/dam/mongolia/Publications/Air\%20Pollution\%20in $\% 20$ Mongolia.pdf

12. China Air 2016. Air Pollution Prevention and Control Progress in Chinese Cities. Clean Air Asia China Office. https://cleanairasia.org/wpcontent/uploads/2016/08/China-Air-2016-Report-Full.pdf

13. S. Kimelman. Voprosy Ekonomiki 7, 52-64 (2010) DOI: 10.32609/0042-8736-20107-52-64

14. A. Makarov, E. Makarova, A. Mikheeva. EKO 49(6), 62-82 (2019). DOI: 10.30680/0131-7652-2019-6-62-82.

15. Official website of the Ministry of Finance of the Russian Federation https://www.minfin.ru/ru/statistics/fedbud/

16. Official website of the Federal State Statistics Service of the Russian Federation. https://www.gks.ru/ 
17. Official site of National Bureau of Statistics of China. http://data.stats.gov.cn/

18. Official site of National Statistical Office of Mongolia. https://www.1212.mn/

19. Databank of the World Bank. https://databank.worldbank.org/

20. B. L. Radnaev, A. S. Mikheeva. Regional Research of Russia. 1, 3 (2011) DOI: $10.1134 / \mathrm{S} 2079970511030117$

21. O. Marchenko, S. Solomin. International Conference of Young Scientists on Energy Systems Research. 114, 4 (2019) DOI: 10.1051/e3sconf/201911405001

22. Mongolia Environmental Performance Reviews Highlights. Information Service United Nations Economic Commission for Europe. Geneva - September 2018. https://www.unece.org/environmental-policy/environmental-performancereviews/enveprpublications/environmental-performance-reviews/2018/environmentalperformance-review-of-mongolia/docs.html

23. Yu Liu, Rong-Lin Li, Yang Song, Zhi-Jiang Zhang. Int J Environ Res Public Health. (2019) DOI: 10.3390/ijerph16224574.

24. China Mineral Resources 2018. Prepared by Ministry of Natural Resources, PRC, Geological Publishing House, Beijing https://www.gov.cn/xinwen/201810/22/5333589/files/01d0517b9d6c430bbb927ea5e48641b4.pdf

25. A. Novoselov, I. Potravny, I. Novoselova, K. Chávez Ferreyra. Economy of Region. 14, 4 (2018). DOI: 10.17059/2018-4-33

26. The Economic Consequences of Outdoor Air Pollution (2016) https://www.oecd.org/environment/indicators-modelling-outlooks/the-economicconsequences-of-outdoor-air-pollution-9789264257474-en.htm

27. Report on the state and environmental protection in Republic of Buryatia in 2015 https://egov-buryatia.ru/mpr/activities/reports_and_reports/gosudarstvennyydoklad.php

28. Report on the state and environmental protection in Irkutsky region in 2015 https://irkobl.ru/sites/ecology/picture/

29. Report on the state and environmental protection in Zabaikalsky region in 2015 https://minprir.75.ru/deyatel-nost/ohrana-okruzhayuschey-sredy/ekologicheskayasituaciya-v-zabaykal-skom-krae

30. Environmental performance review of China. Conclusions and recommendations (final). OECD Working Party on Environmental Performance, Beijing, 2006 https://www.oecd.org/env/country-reviews/37657409.pdf

31. C. Ge, S. Wu, Y. Wu. Financing environmental investments in China: a preliminary study. Chinese Research Academy of Environmental Sciences, China, Investment Institute, State Development Planning Commission, China http://www.caep.org.cn/ywlm/home/working_pagers_and_reports/working_papers/201 809/W020180929352239972580.pdf

32. H. Peng, X. Lu, C. Zhou. System Journal of Service Science and Management. 11, 94100 (2018) https://doi.org/10.4236/jssm.2018.111009 